\title{
Psychiatry as ideology in the USSR
}

Sidney Bloch Department of Psychiatry, University of Oxford, Warneford Hospital, Oxford

This paper was given as a talk at the Venice Biennale on 9 December 1977. It was part of a symposium on 'The Freedom of Science - Problems of Science of Scientists in Eastern Europe'. Dr Bloch details some of the problems of psychiatry and its vulnerability to improper use and thus the dilemmas which must ensue in day to day practice. He looks at psychiatry in the USSR and the system within which Soviet psychiatrists must work. The Communist Party and career advancement for psychiatrists would appear to be closely related and it is suggested that, in all probability, the majority of psychiatrists are as perturbed at the misuse of their profession as their Western colleagues, but act compliantly out of fear. Severe punishments have been imposed on those psychiatrists who have dared to speak out against the régime and the system as operated. Dr Bloch concludes by urging Western psychiatrists to do all they can to help their Soviet colleagues to initiate a return to an independent and autonomous psychiatric profession.

\section{Introduction}

Throughout its history, psychiatry has been bedevilled by problems which make it more vulnerable to improper use than any other branch of medicine. Among these problems are the lack of objective criteria in the definition of most of the conditions the psychiatrist treats and the resultant poor agreement on diagnosis, the meagre information available on the effectiveness of treatments, and the ill-defined boundaries of the psychiatrist's role.

Despite these limitations, the psychiatrist is empowered by society to assume such awesome responsibilities as detaining a person in a hospital against his will, and serving as an expert court witness in providing testimony on whether a defendant is mentally responsible or not for the commission of an offence. He is thus granted exceptional authority to determine the fate of others while at the same time suffering, in making his judgements, from inadequate knowledge and limited scientific objectivity. It is an unfortunate fact that psychiatry in 1977 is still at a fairly primitive stage in its development.

Not surprisingly the psychiatrist faces a number of dilemmas in his day to day practice. One of the most notable of these is dual loyalty; commonly the interests of the patient are in conflict with the aims and policies of the institution which employs the psychiatrist. Questions of allegiance may arise fo $\vec{D}$ psychiatrists working in settings such as prisons $\overrightarrow{2}$ criminal courts, the army, universities or governsw mental bodies. The example of the military psy chiatrist springs readily to mind; his employer wilto have no doubt that the doctor's foremost loyalty if to the overall organisation while the ill soldier may feel quite differently. To whom does the psychiatrisf owe his primary allegiance in a situation of this kind and how does he arrive at his decision?

In recent years the psychiatrist has been accused $\vec{b}$ of serving the establishment: offering his expertise in order that the status quo will be preserved. ${ }^{1}$ Thus a criterion of recovery from illness in common use is 'adjustment to society', with the implication that such adjustment reflects mental health. Some criticso go further, particularly members of the radicabo psychiatry movement, by depicting the psychiatisit as an oppressor. ${ }^{2,3}$ By this labelling and classify of patients, they contend, the psychiatrist has takern on the role of social engineer and has contributech his technology to the regulation and control of human behaviour.

The nebulous nature of the concept of menta를 illness has also had another important effect. The psychiatrist's perception and attitude to it togethe with his theories and practice have, throughout the history of the discipline, been closely interwoven with the norms, values and ideologies of the society within which he functions. The field of sexuab behaviour offers excellent illustrations: masturbation in the last century was regarded by the medica? profession as a distinctly, pathological condition with a variety of unpleasant complications while in? the 1970 s there has been heated debate among the ranks of psychiatrists as to whether or not homosexuality should be considered a disease. ${ }^{4}$ In both instances, the psychiatrist has tended to echo the values and sentiments of dominant public opinion

An American psychiatrist, Seymour Halleck, has argued trenchantly that whether the psychiatrist likes it or not, he is a political being. Even when he strives to practise his profession in a neutral and objective manner, his very neutrality constitutes a political posture. Halleck's thesis makes sense when we bear in mind the nature of the predicaments $\mathrm{I}_{\mathbb{D}}$ have sketched above.

Although these predicaments are universal, they $\Omega$ 
are probably aggravated by certain conditions particularly those prevailing in a totalitarian society. This brings us to a consideration of the position of the psychiatrist in the Soviet Union. What factors operate there which affect his role as a professional ? What ethical problems confront him in his day to day practice? Can he attempt to resolve these problems ?

\section{The psychiatrist in the USSR}

Soviet psychiatrists have achieved a certain notoriety in recent years as a result of their systematic and pervasive misuse of their profession for political ends. The voluminous evidence available since I97 I shows that some of them have undoubtedly compromised themselves by declaring sane dissenters as mad and in need of compulsory treatment. ${ }^{6}$ Perhaps by examining the roots of this perversion of medicine, we can understand the factors that shape the relationship between the psychiatrist and the Soviet state. First, I shall focus on the organisation of the psychiatric system in the USSR and show the widespread effects on it of political forces; then I shall examine psychiatric theory and practice and their relationship to the ideologies and values of the communist state.

\section{The psychiatric system}

Every Soviet psychiatrist is a state employee. The vast majority work for the Ministry of Health; the rest for the Ministry of the Interior (those with jobs in the special psychiatric hospitals for the criminally insane) or for the military. The system of State as sole employer obviously limits the psychiatrist's independence: he has no option other than to work within the state structure; no alternatives like private professional practice or employment by a private hospital or private university - as is the case in the West - are available to him.

His independence is further curtailed by psychiatry's rigid, hierarchical nature. With the Revolution, the organisation of medical services, including psychiatry, became highly centralised and the model of local government, the Zemstvo, devised 50 years earlier and responsible for medical care, was entirely re-vamped. Planning and implementation of psychiatric services have remained until today the responsibility of the federal Ministry of Health in Moscow. Although each of the Soviet republics has its own health department they are all subordinate to the federal ministry. All major policies thus emanate from Moscow and innovation from any other source is unusual. In practice, decisions on all new developments are made only at the highest levels and their implementation is axiomatically carried out throughout the country. In this way, a striking uniformity of practice is achieved.
The chief psychiatrist at the Ministry of Health, currently Dr Zoya Serebryakova, wields enormous power since all policies, no matter what their origin, must be approved by her. In her decision making, she is influenced by an important body, the Institute of Psychiatry of the Academy of Medical Sciences. The Institute, in addition to its advisory role, determines to a large extent training and research policy in psychiatry throughout the Soviet Union. The present director and deputy director, Professors Andrei Snezhnevsky and Ruben Nadzharov respectively, are therefore among the most powerful figures in the Soviet psychiatric establishment. We might note in parentheses that the three psychiatrists we have named so far all figure prominently within the context of the political abuse of psychiatry; I shall suggest an explanation for this later.

With planning of services and their co-ordination and control so tightly centralised and because of the rigid hierarchy in the Soviet psychiatric bureaucracy, the employee is obliged to submit to official directives and has almost no leeway in exercising independent professional judgement.

\section{Psychiatry and the Communist Party}

With so much power invested in a small group of psychiatrists at the peak of the pyramid, a natural question follows: who reaches position of authority? Here we see the pivotal role of the Communis Party. I need not remind my fellow Russian panelistso that the party has a central managerial role in alf facets of Soviet life including the psychiatric profession. By ensuring that party members are situated at all levels of the health system, particularly in positions of responsibility, both in the Ministry of Health and in psychiatric institutions, the party and thus the régime, maintains control of all psychiatric services and orchestrates all policy.

Only a minority of psychiatrists are party members. Field 7 cites an estimate of $I$ in 5 for doctors generally. The party, as we know, has a limited membership and admission is associated with such factors as political achievement and obedience to directives. Continuing membership calls for total subordination to the party's policies and ideologies. With this in mind we should note that the 20 per cent of physicians who are party members are not distributed equally throughout the health service but are to be found mainly in positions of authority.

The importance of political qualifications - $\mathfrak{W}$ reflected mainly in party membership - in attaining a high position among the profess onal ranks stems from the Stalin period. Stalin himself proclaimed $\mathbb{D}$ that political qualifications - loyalty to the party and $\stackrel{?}{-}$ its ideology and a readiness to obey party directives $-\frac{T}{0}$ took priority over professional ability and experience. $\frac{O}{\mathbb{D}}$

The issue of allegiance discussed earlier comes $\cong$ into sharp relief here: the psychiatrist is inevitably $\stackrel{\mathbb{Q}}{\Omega}$ 
faced with a dual loyalty, on the one hand to the party and on the other to his patients. Also clear is the path to professional power - the need to serve the demands of a political machine.

The party also infiltrates into the life of the ordinary psychiatrist in at least two critical ways political studies in his medical education and the oath he swears (of course the medical profession as a whole in the Soviet Union is affected). Twentyfive per cent of the medical student's curriculum is devoted to the study of political subjects: MarxismLeninism, political economy, dialectical materialism, historical materialism, history of the Communist Party, and scientific atheism; indeed more time is allocated to these subjects than to surgery. Obviously a student can harbour his own private views on both the issue of being taught such material and on the content itself, but he is left in no doubt as to the significance attached by the régime to the need for a political education. Later, on his graduation, he will be reminded of this significance. Thus an issue of Medical Worker, the organ of the Ministry of Health, asserts that 'in order to be a working representative of the physician's noble profession, it is necessary not only to have an excellent professional education, but also to be well acquainted with the principles of Marxism-Leninism' ${ }^{8}$

The Soviet physician's oath, adopted on 26 March I97I by the praesidium of the Supreme Soviet, calls for the doctor's awareness of communist ideology by the inclusion of this statement: 'that I will in all my actions be guided by the principles of communist morality ever to bear in mind the high calling of the Soviet physician and my responsibility to the people and the Soviet state'. ${ }^{9}$ Although another clause in the oath instructs the doctor 'to be attentive and thoughtful of the patient, to maintain medical confidence', the emphasis overall is on the collective, on the state.

The state's monopoly as sole employer, the centralised and rigid hierarchy inherent in the medical bureaucracy, the role of the Communist Party especially at levels of authority, and the inculcation of communist morality in the physician by political studies in his medical education, and by the oath he takes, all contribute to the politicisation of the psychiatrist and, generate various ethical problems : the dilemma of to whom to pay allegiance, the lack of independence as a professional, and an undermining of objectivity in medical judgements. They also provide fertile soil for the garmination of non-medical applications of psychiatry.

\section{The theory and practice of Soviet psychiatry}

Let us now turn to the theory and practice of psychiatry in the Soviet Union. Here too the profession is markedly influenced by socio-political factors. I can illustrate this influence by examining two developments in Soviet psychiatry: the death of Freudianism in the 1930 s and the ideologica reverence for Pavlov 20 years later.

At the turn of the century and up to the Revolum tion, Russian and Western psychiatric practices. were fairly similar in orientation. Freud's theories? for instance were accepted by a number of psy $\overrightarrow{\vec{F}}$ chiatrists in the first few years of the Bolshevij period and efforts were even made to amalgamate these theories with those of Marxism. A society of psychoanalysts was founded. The virtual oblitera $\widetilde{\widetilde{\Phi}}$ tion of Freudianism however began in the 1930 s when Stalin's political controls infiltrated every facet of life and Soviet medicine became isolateक from Western influences. Psychoanalysis was. officially pronounced as pseudo-scientific and reactionary, that is, in both scientific and ideologicas terms. ${ }^{10}$ The translation of Freud's works cease $\bar{b}$ and previously translated material became almosi inaccessible. This development amounted to $a$ form of pseudo-censorship since the psychiatris interested in Freudian psychology would have encountered considerable obstacles in obtaining an $\vec{y}$ of his books. The same applied to the works of Jung/ and Adler and representatives of the neo-Freudiane school. Thus a substantial and important area of psychiatric thought became effectively taboo to the Soviet psychiatrist. The antipathy to Freud has persisted to the present. For example, Professoto D Fedotov, in an article on Freud in 1958, aver:e्ts that it is:

‘. . basically false and speculative, ignores the rầ of aetiology, the physiological mechanism of disease and denies the deterministic significance of the external milieu. . . . Precisely because of the asser $\frac{\mathbb{}}{2}$ tion of the primacy of instincts over conscious action and the limiting of the role of social factors? in determining human conduct, Freudianismconstitutes a weapon of bourgeois reaction. The centre of contemporary Freudianism is the USA which, as is well known, is also the centre of world imperialism'.11

Many of Fedotov's arguments have been made by other critics and are perfectly reasonable. Identify- 극 ing Freudian theory as a bourgeois weapon and relating it to imperialism, is rather ludicrous. In an? intensely ideological state like the Soviet one, the reasons for such fiery condemnation are not difficulte. to establish. Firstly, communist ideology could not possibly tolerate the notion that man's behaviour is ruled by irrational, egoistical instincts, which reside in the dark labyrinth of the unconscious. On the $\mathrm{e}^{\mathrm{W}}$ contrary, his acts and thoughts are the result of $a$ ? complex of social, economic and viological factors.? Secondly, the psychoanalyst's encouragement to the patient that headopt an independent and autonomous ${ }^{-}$ stance and be responsible for himself contradicts ${ }^{\circ}$ the salient position of the collective in Soviet $\frac{\text { ? }}{\mathbb{D}}$ ideology. For the Soviet, the aim of treatment? is the patient's re-integration into the community 2 
and his adoption of an attitude of social responsibility: the needs of the collective take priority over those of the individual.

The second illustration of political influences on psychiatric theory centres on the figure of Pavlov. In I950 a joint session of the Academies of Science and Medical Science, following party dictate, cemented the Pavlovian basis of medicine as well as a number of other scientific disciplines: his theories were to be extensively developed and applied to medical practice. The conference ushered in a particularly unsavoury chapter in the history of Soviet science; charlatans, like Lysenko in genetics, were granted complete control by party ideologues to promulgate their own dogma whilst their opponents were purged.

Psychiatry was not spared this turmoil, and antiPavlovian psychiatrists, many of them Jewish, were demoted from any important positions they might have held. The period generally was characterised by flagrant anti-Semitism culminating in the notorious Doctors' Plot of 1953. The Pavlov session also had a distinct nationalist flavour; the aim was to inaugurate a campaign whereby the superiority of Soviet medicine over its Western counterpart would be demonstrated.

Psychiatrists who played their political cards correctly, party careerists in the main, assumed leadership of the profession then, and have continued to retain it since. A prominent representative of this group is Professor Snezhnevsky who, in effect, led the Pavlovian camp in 1950. His school, centred in the Institute of Psychiatry in Moscow, gradually came to dominate during the I950s and $60 s$, the theory and practice of psychiatry throughout the USSR. Although groups of psychiatrists in Leningrad and Kiev attempted to stave off what they regarded as a retrogressive step, they were ultimately pressed into submission. During the Krushchev period, although the dominance of Pavlovian doctrine waned, its original adherents continued to hold their top positions. The 'Pavlov' episode could not serve as a better example of the blatant tampering of the medical profession by political forces.

\section{Subsequent theoretical developments}

Pavlovian psychiatry was associated with a marked biological orientation: abnormal behaviour was perceived as stemming from disturbances in higher nervous activity. Not unexpectedly the last two decades have seen a tremendous amount of attention paid to biological, particularly genetic, research and to an emphasis on physical treatments, mainly with drugs. The former concept that mental illness was the product of social forces could not conveniently explain the occurrence, in a socialist society, of such conditions as alcoholism, neurosis and homosexuality. With the advent of the Pavlovian school however, they could be readily categorised as inherited disorders.

The most crucial development arising out of the Pavlov era has been the immense widening of the criteria for the definition of mental illness, and of schizophrenia in particular. ${ }^{12}$ Professor Snezhnevsky and his colleagues have introduced a unique scheme for the classification of this condition, a scheme which has facilitated its application to even the mildest behavioural change. ${ }^{13}$ This is not the place to examine the details of the diagnostic system; rather let me try and show what implications it has had for the contemporary Soviet psychiatrist.

Our discussion leads us to consider, more specifically, how dissenting behaviour has become labelled as evidence of schizophrenia. Of the three forms of schizophrenia proposed by Snezhnevsky, the continuous form is the one most commonly diagnosed in dissenters. The slowly progressive variant of this continuous form is termed 'sluggish', since its onset is so insidious as to be barely discernible and the patient retains almost full ability to function socially. The course of the illness however is progressive and the final outcome is poor. The fact that only the specialist's eye can perceive the presence of the disease has given rise to the new concept in Soviet psychiatry of 'seeming normality'. The patient appears normal to hig oo family and friends yet harbours the illness.

For example, in the clinical judgement Professor Lunts, the psychiatrist witness in the trial of the human rights activist Natalya Gorbanevskaya, she suffered from schizophrenia of the sluggish variety. Although she had presented no clear symptoms and had appeared to behave normally, this was not so from the 'theoretical point of view'. Thus Professor Lunts proffered the absurd concept that schizophrenia can be theoretically, but not clinically, present in a patient. ${ }^{14}$

Why has the Soviet concept of mental illness broadened so considerably during the last decade? This development has in fact coincided with the $\delta$ widespread misuse of psychiatry for political ends. I doubt that the association is fortuitous. The $\circ$ available evidence points convincingly to the adoption in the mid-1960s of a state policy to? harness the services of the psychiatric profession.

The psychiatric gambit for the suppression of $\mathcal{N}$ dissent is a perfectly logical development. At a timen when the policy of détente was being carefully N cultivated and trumped-up trials were no longer $\omega$ feasible, the definition of non-conformist ideas ideas which posed a major threat to the régime as symptoms of insanity, provided an alternative and convenient strategy to stem the rising tide of dissent. Psychiatry as a political weapon has a number of advantages: the dissenter charged with an anti-Soviet crime and declared insane and non- $\frac{?}{\mathbb{D}}$ responsible loses any chance of defending himselfo 
at his trial which becomes a mere formality; the risk of his friends demonstrating outside the courtroom is also minimised. Once interned in a mental hospital - unlike a labour camp or prison sentence, this is for an indeterminate period - the dissenter is surrounded by genuinely disturbed, often dangerous patients; given drugs for their side effects rather than their therapeutic benefits; loses all his rights; and is pressed into the morally compromising position of recantation. A psychiatric label is also particularly handy in discrediting the ideas of Marxists or party dissenters, which may prove attractive to liberals within the party leadership and possibly pave the way for a schism in their ranks.

Moreover the psychiatric grip on the dissenter does not end when he is released from hospital: he is placed on a register for the 'socially dangerous' which permits the psychiatrist to keep a close watch on him. By this means, the KGB has taken into its employ the psychiatrist as a deterrent force. One curious result of this arrangement is the National Holiday Syndrome and other exotic conditions like 'Nixonitis'. It is now well-documented that for two or three weeks around May Day and Revolution Day, the mental hospitals are used as temporary prisons for 'socially dangerous' individuals who otherwise might protest in public or indulge in other deviant behaviour. A similar preventive programme obtains during the visits of foreign dignitaries.

The non-medical factors affecting admission to hospital of the dissenter are equally cogent in determining his release. There appear to be only two reliable methods for him to gain his discharge both are political in nature: first, recantation 'Yes, my ideas about the invasion of Czechoslovakia or about the régime's lack of respect for the constitution or about my wish to emigrate or about my religion, etc. are the product of my diseased mind ... with the treatment I am receiving, I have become aware of their erroneous nature and will discard them from now on ...; ; second, the level of Western protests - during the past five years one can plot the discharge rate of prominent dissenters with the volume of campaigning on their behalf in the West. When it has become clear to the authorities that the psychiatric internment of a dissenter has drawn too much unfavourable publicity - the case of Leonid Plyushch illustrates this point well ${ }^{15}$ - his release inevitably follows, and not infrequently his forcible exile from the USSR.

\section{The psychiatrists involved in the abuse}

Finally, we must pose a crucial question: which Soviet psychiatrists participate in the abuse - the entire profession or only a minority, and what factors motivate the psychiatrists who are involved? Do they genuinely believe that dissent is a form of illness ?
Although not clear cut, psychiatrists acn be placed along a continuum in terms of their involve- $a$ ment - a small core group at one end, a minute dissenting group at the other, and the majority of average psychiatrists between them. The core group.? comprises some 50 psychiatrists; many of their names appear repeatedly in the psychiatric com $-\overrightarrow{0}$ missions which have diagnosed dissenters as mentally ill. On occasion they have reversed the conclusion of another psychiatric panel that $a \overrightarrow{\mathrm{D}}$ dissenter is sane (this occurred in the two well documented cases of Natalya Gorbanevskya and ${ }^{\infty}$ General Grigorenko). The evidence which shows $\overrightarrow{0}$ the close collaboration between these psychiatrists $\overrightarrow{-}$ and the régime is now overwhelming.

As for their motives. Their acceptance of dissent as evidence of illness is highly unlikely. All emigré Soviet psychiatrists I have interviewed report their: rejection, and that of their former colleagues (at ${ }^{\omega}$ least privately), of the diagnostic concepts created by the Snezhnevsky school. Furthermore, theo testimony of a dozen ex-dissenter 'patients' I have spoken to in the West and in the USSR substan- $c$ s tiates this picture: almost all the psychiatrists theyo dealt with, though refraining from open expression $\frac{\mathbb{D}}{3}$ of their views, revealed enough to indicate that theyo did not regard the dissenters as ill.

Many core group psychiatrists occupy senior $\vec{\theta}$ administrative or academic positions; and almosto certainly, most if not all are party members. Clearty psychiatrists like Serebryakova, Snezhnevsky apid Nadzharov have reached powerful positions because of their political qualifications and their prepared-ฏ ness to connive with the demands of the party. 을 Apart from their positions of authority, they have also been rewarded in other ways: their salary iso응 considerably higher than that paid to ordinary psychiatrists, foreign travel (the composition of the Soviet delegation to international psychiatric conferences is fairly predictable and the same faces appear repeatedly), a country dacha, and access to other privileges and benefits not available to the 3 . average citizen. The contract between political 8 functionary and core group psychiatrist is guaranteed $\frac{3}{\xi}$ provided the latter remains a faithful collaborator.

The vast majority of psychiatrists are, in all likelihood, as perturbed at the misuse of their profession $\frac{7}{0}$ as their Western colleagues but act compliantly out of fear. They know full well the risk entailed in $N$ openly criticising the régime or those psychiatrists N who have colluded with it: professional suicide, $N$ professional ostracism, even a prison sentence. The handling of such an unenviable moral predicament is to keep well away from the dissenter, and if this $\stackrel{O}{C}$ is unavoidable, to retreat from the case as speedily as possible. When involved, some psychiatrists have attempted to express their humanitarian inclinations but always covertly, so as to protect themselves.

The dissenting psychiatrist group is minuscule; $I \frac{O}{\mathbb{D}}$ am aware of only two psychiatrists - Semyon 음 
Gluzman and Marina Voikhanskaya, who have openly condemned the Soviet malpractices. Both have paid dearly for exercising their professional conscience. Dr Gluzman has now spent five years of a seven-year sentence in a labour camp for his authorship of a critical account of the official psychiatric report on General Grigorenko, in which he documented the intentional deceit of the psychiatrists' arguments. ${ }^{16} \mathrm{Dr}$ Voikhanskaya began to protest about the internment of sane dissenters in her hospital in Leningrad from 1974 and has continued to do so since her emigration to the West. ${ }^{17} \mathrm{Her}$ outspokenness has not gone unpunished : her eleven-year-old son has been barred since I 975 from emigrating to join her.

\section{Conclusion}

The harsh treatment meted out to Drs Gluzman and Voikhanskaya demonstrates unequivocally the extent to which Soviet psychiatry has suffered at the hands of the State. The systematic misuse of psychiatry as an instrument of repression is the culmination of a long process of ideological infiltration by the régime.

With the Soviet system so profoundly dominated by ideology, it may be naive to expect the return of an independent and autonomous psychiatric profession. Yet Western psychiatrists should do all they can in supporting their Soviet colleagues to achieve this goal.

\section{References}

${ }^{1}$ Halleck, S L (1968). Psychiatry and the status quo. Archives of General Psychiatry, 19, 257-265.

${ }^{2}$ Liefer, R (1970). The medical model as ideology. International fournal of Psychiatry, 9, 13-21.
sTalbot, J A (1974). Radical psychiatry: an examination of the issues. American fournal of Psychiatry, 131, I2I-I28.

'Stoller, R J, Marmor, J, Bieber, I, Gold, R, Socarides, C W, Green, R, and Spitzer, R L (1973). A symposium: should homosexuality be in the American Psychiatric Association nomenclature? American fournal of Psychiatry, 130, 1207-1216.

${ }^{5}$ Halleck, S L (1971). The Politics of therapy. Science House, New York.

'Bloch, S and Reddaway, P (1977). Russia's political hospitals. Gollancz, London.

'Field, M G (1957). The doctor and patient in Soviet Russia, Harvard University Press, Cambridge.

${ }^{8}$ Quoted in Field, M G (1967). Soviet socialized medicine: An introduction. Free Press, New York, p. 33.

'Meditsinskaya Gazeta, 20 April 1971. English translation in Survey, Autumn 1971 (81).

${ }^{10}$ Segal, B M (1975). The theoretical bases of Soviet psychotherapy. American fournal of Psychotherapy, 29, 503-523.

11Fedotov, D (1958). Freudianism - a reactionary manifestation of bourgeois ideology. Meditsinki Rabotnik, 25 November. Quoted in Field, M G (1960). Approaches to mental illness in Soviet $\mathscr{D}$ society: some comparisons and conjectures. Social Problems, 7, 277-297.

${ }^{12}$ The international pilot study of schizophrenia, (1973). Vol. I. World Health Organization, Geneva.

${ }^{13}$ Holland, J and Shakhmatova-Pavlov, I V (1977). Concept and classification of schizophrenia in the Soviet Union. Schizophrenia Bulletin, 3, 277-287.

${ }^{14}$ Chronicle of Current Events, (1970), No. 15.

${ }^{15}$ Khodorovich, $T$ (ed.) (1976). The case of Leoni Plyushch. C Hurst, London.

${ }^{16}$ Gluzman, Semyon (1977). The imprisoned conscience of Soviet psychiatry. Working Group on the Internment of Dissenters in Mental Hospitals, London.

${ }^{17}$ Voikhanskaya, $M$. Life in an ordinary mental hospital: the view of a Soviet psychiatrist. In Bloch and Reddaway, op. cit., pp. 458-462. 